\title{
KOMANAJEMEN SUMBER DAYA ANTARA PEMERINTAH DESA, LEMBAGA ADAT DAN MASYARAKAT (KASUS KAWASAN PANTAI DESA JUNGUT BATU, NUSA PENIDA, BALI)
}

\author{
Riyanto Basuki*) dan Victor P.H. Nikijuluw")
}

\begin{abstract}
ABSTRAK
Tujuan dari tulisan ini adalah untuk melihat proses terjadinya pengelolaan sumber daya alam secara bersama (komanajemen). Komanajemen oleh pemerintah dan masyarakat dianggap sebagai tipe pengelolaan yang cukup efektif di Desa Jungut Batu, Nusa Penida, Bali. Hal ini ditunjukkan dengan meningkatnya pendapatan dan kesempatan kerja di bidang budidaya rumput laut. Bentuk komanajemen di daerah penelitian adalah hubungan kemitraan antara pemerintah desa, lembaga adat dan masyarakat dalam menterjemahkan peraturan formal pemerintah pusat ke dalam bentuk yang dapat dimengerti dan dilaksanakan oleh masyarakat setempat. Peraturan komanajemen bisa dilaksanakan efektif karena masyarakat merasakan manfaatnya di samping adanya dukungan adat dan agama.
\end{abstract}

\section{ABSTRACT: Natural Resource Co-management between Village Govern- ment, Customary Institute and Society (A case in Coastal Zone of Jungut Batu, Nusa Penida, Bali). By : Riyanto Basuki and Victor P.H. Nikijuluw.}

The purpose of this paper is to evaluate the background and establishment process of collaboration in natural resource management (Co-management). Co-management between government and society is found to be effective mechanism in Jungut Batu Village, Nusa Penida, Bali Island. The effectiveness is attributable to higher income and more employment opportunity in seaweed culture. The type of co-management is that cooperation in planning and enforcement of local rules by village government, customary institute and villagers. The local rules are formed on the basis of and inspired by the national rules. The rules of co-management could be effectively implemented since people can derive benefit. Supports of custom and religion in this matter are imperative.

KEYWORDS: Co-management, collaboration, income, employment.

\section{PENDAHULUAN}

Untuk mencapai pemanfaatan sumber daya perikanan secara berkelanjutan dan demi menghindari apa yang umumnya dikenal dengan "tragedi milik bersama", manajemen atau pengelolaan sumber daya harus dilakukan secara bersungguh-sungguh. Umumnya diasumsikan bahwa pengelolaan sumber daya perikanan adalah tanggung jawab pemerintah. Sebaliknya pengguna atau mereka yang memanfaatkan sumber daya yang dapat terdiri atas nelayan, koperasi nelayan, masyarakat desa pantai, perusahaan swasta nasional dan asing, merasa tidak memiliki tanggung jawab dalam pengelolaan sumber daya perikanan.

Pemerintah pada tingkat pusat dan daerah sebagai "manajer" mengelola sumber daya perikanan dengan berbagai mekanisme. Sebagai contoh dalam perikanan tangkap, dikenal sistem lisensi terutama bagi nelayan skala besar. Mekanisme yang lain dapat

Peneliti pada Balai Penelitian Perikanan Laut Muara Baru, Jakarta 
berupa zonasi daerah penangkapan, pembatasan jumlah alat, pelarangan alat tertentu seperti pukat harimau dan penangkapan ikan dengan menggunakan bahan peledak, pelarangan penangkapan ikan jenis tertentu secara berlebihan serta pengaturan jumlah tangkapan yang diperbolehkan.

Selain dari mekanisme yang berkaitan langsung dengan sumber daya ikan, pengelolaan dapat juga dilaksanakan melalui mekanisme hukum positif pada sektor lain. Sebagai contoh, UU No 4 tahun 1972 tentang Ketentuan-ketentuan Pokok Pengelolaan Lingkungan Hidup memiliki dimensi pengelolaan sumber daya perikanan, meskipun UU ini lebih banyak mengatur tentang lingkungan hidup dalam spektrum yang luas.

Meskipun peraturan formal dan hukum positip sudah digunakan oleh pemerintah dalam pengelolaan, namun pelaksanaan atau implementasinya belum begitu efisien. Jentoft (1989) menyatakan bahwa kurangnya efisiensi hukum positip disebabkan oleh fenomena global dalam perikanan tangkap. Korten (1981) mengajukan empat alasan mengapa pengelolaan sumber daya perikanan secara terpusat tidak atau kurang efektif: (1) jangkauan yang terbatas, (2) ketidakmampuan mendayagunakan kapasitas penduduk lokal, (3) tidak sesuai dengan kebutuhan nyata yang dialami penduduk, serta (4) men. ciptakan kondisi ketergantungan penduduk desa pada orang luar dan secara perlahan membunuh inisiatif lokal.

Pendekatan pengelolaan secara bersama atau komanajemen dianggap sebagai alternatif yang lebih baik di dalam pengelolaan sumber daya perikanan (Jentoft, 1989; McCay, 1993; Pomeroy dan Pido, 1995). Komanajemen berarti bahwa lembaga pemerintah dan nelayan secara kemitraan melak. sanakan pembagian kewajiban dan otoritas dalam pengelolaan perikanan (Pomeroy dan Williams, 1994). Proses terjadinya komanejemen dapat dalam bentuk: (1) lembaga pemerintah secara formal mengakui peraturan yang secara informal sudah diimplementasikan nelayan, dan (2) otoritas pelaksanaan suatu peraturan formal diserah. kan dari pemerintah kepada nelayan.
Hirarki bentuk-bentuk komanajemen di antaranya dikemukakan oleh Pomeroy dan Williams (1994); McCay (1993); dan Berkes (1994). Menurut mereka, bentuk-bentuk komanajemen itu terletak antara dua kutub yaitu secara terpusat oleh pemerintah dan secara lokal oleh masyarakat (Gambar 1). Bila pengelolaan sumber daya dilakukan sendiri oleh pemerintah atau oleh masyarakat maka komanajemen tidak terwujud. Komanajemen akan ada, jika terdapat pembagian tanggungjawab, otoritas dan kewajiban antara pemerintah dan masyarakat lokal.

Berdasarkan hirarkinya, komanajemen berawal dari bentuk di mana otoritas pemerintah pusat sangat kuat (bentuk pelaporan), hingga bentuk di mana pemerintah pusat sudah kurang otoritasnya sementara masyarakat lokal semakin besar peranannya (bentuk koordinasi antar lokasi). Pada komanajemen yang berbentuk "pelaporan", pemerintah pusat hanya melaporkan pada masyarakat lokal tentang kebijakankebijakan yang diberlakukan atas sumber daya. Sementara pada komanajemen "kontrol masyarakat" atau "koordinasi antar lokasi", masyarakat lokal melaksanakan seluruh fungsi pengelolaan dan hanya melaporkan pada pemerintah pusat. Bentuk komanajemen moderat adalah di mana pemerintah dan masyarakat memiliki peranan yang sebanding yaitu "komunikasi", "pertukaran informasi", "kebijaksanaan bersama", dan "kemitraan".

Penelitian ini merupakan salah satu upaya dokumentasi dan evaluasi bentukbentuk komanajemen wilayah laut dan pesisir di Indonesia. Pemilihan lokasi Desa Jungut Batu berdasarkan atas informasi yang diperoleh dari Dinas Perikanan Prop. Bali dan Dinas Perikanan Kabupaten Klungkung bahwa partisipasi masyarakat desa dalam pengelolaan pantai sudah dilakukan di daerah ini. Dengan diketahuinya komanajemen di Bali, maka bertambahlah dokumentasi tentang praktek komanajemen dan peranan masyarakat lokal dalam pengelolaan laut dan pesisir di Indonesia. Selain melakukan dokumentasi, penelitian ini bertujuan melakukan evaluasi kinerja komanajemen berdasarkan kriteria produktivitas, keberlanjutan dan pemerataan. 


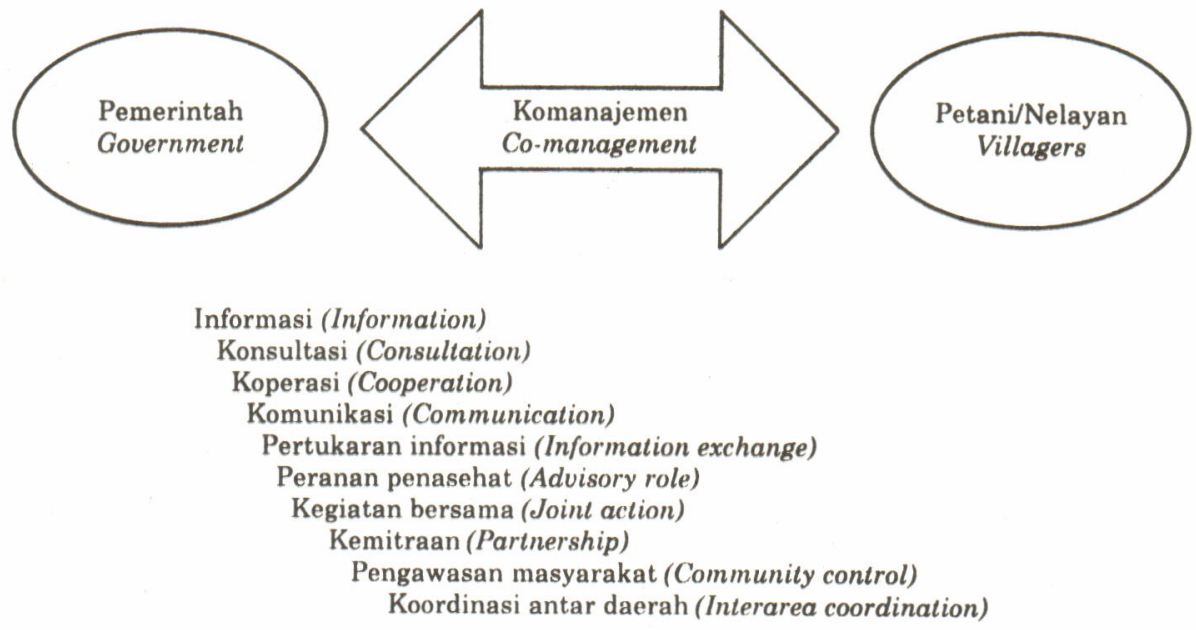

Gambar 1. Susunan hirarki komanajemen (Pemeroy dan Williams, 1994; Berkes, 1994).

Figure 1. The hierarchy of co-management arrangements. (Pomeroy and Williams, 1994; Berkes, 1994).

\section{METODE PENELITIAN}

Pengumpulan data untuk tulisan ini dilakukan dengan cara survei menggunakan kuesioner ke pada 30 orang nelayan (petani rumput laut). Setelah diadakan validasi, hanya 28 responden yang digunakan dalam analisis. Proses validasi dilakukan dengan cara pengecekan silang yang mencakup informasi antar responden dan tokoh kunci. Data juga dikumpulkan dari wawancara dengan tokoh masyarakat, pimpinan formal dan informal di tingkat desa. Penelitian ini diadakan pada bulan April 1995. Untuk analisis usaha (pendapatan), waktu yang menjadi rujukan adalah pendapatan tahun 1992 sebelum komanajemen efektif berlaku, dan pendapatan tahun 1995 yaitu pada saat penelitian.

Analisis keberadaan serta dampak komanajemen pada tulisan ini berdasarkan kerangka pemikiran yang dikembangkan oleh Pomeroy (1994). Keberadaan suatu bentuk pengelolaan sumber daya ditentukan oleh ada tidaknya landasan institusi (syarat esensial) dan struktur organisasi (syarat opsional). Landasan institusi mencakup tujuan serta norma atau kaidah. Sedangkan struktur organisasi mencakup cara-cara pelaksanaan dan pengawasan norma atau kaidah tersebut.
Dampak suatu komanajemen dapat dilihat dari kriteria efisiensi, merata (equitable) dan keberlanjutan (sustainable). Ketiga kriteria ini dikaji secara bersama atau serempak untuk menentukan baik tidaknya kinerja suatu bentuk komanajemen terhadap kehidupan masyarakat pengikutnya (adherents).

Kriteria efisiensi komanajemen dapat diukur dengan pengamatan berpasangan (Walpole, 1982) sebagai berikut:

$$
\begin{gathered}
t p=\frac{d_{k t}-\mu}{S_{k t}} \sim t \propto(N-1) \\
d_{k t}=\frac{\sum_{i=1}^{N}\left(X_{i k}-X_{i t}\right)}{N}
\end{gathered}
$$

di mana:

$$
\begin{aligned}
& \mathrm{tp}_{\mathrm{i}}= \text { Uji } \mathrm{t} \text { pengamatan berpasangan } \\
& \mathrm{X}_{\mathrm{ik}}= \begin{array}{l}
\text { pendapatan responden } \mathrm{i} \text { setelah ada } \\
\text { komanajemen }
\end{array} \\
& \mathrm{X}_{\mathrm{it}}= \begin{array}{l}
\text { pendapatan responden } \mathrm{i} \text { sebelum } \\
\text { ada komanajemen }
\end{array} \\
& \mathrm{S}_{\mathrm{kt}}=\begin{array}{l}
\text { standar deviasi beda antara pen- } \\
\text { dapatan sebelum dan sesudah ko- }
\end{array} \\
& \mathrm{N}=\begin{array}{l}
\text { manajemen } \\
\text { Jumlah responden }
\end{array}
\end{aligned}
$$


Kriteria keputusan di mana komanajemen memberikan hasil yang lebih efisien tercapai bila:

$$
\mathrm{tp}>\mathrm{t} \alpha(\mathrm{N}-1)
$$

Kriteria "merata" dapat ditentukan dengan cara:

$$
\begin{aligned}
& K K P_{k}=\frac{3\left(\bar{x}_{k}-M_{k}\right)}{S_{k}} \\
& K K P_{t}=3 \frac{\left(\bar{x}_{t}-M_{t}\right)}{S_{t}}
\end{aligned}
$$

di mana :

$$
\begin{array}{ll}
\text { KKP } & =\text { Koefisien Kemiringan Pearson } \\
\bar{x} & =\text { Nilai tengah pendapatan } \\
\mathrm{M} & =\text { Median pendapatan } \\
\mathrm{S} & =\text { Standar deviasi } \\
\mathrm{k} & =\text { Sesudah ada komanajemen } \\
\mathrm{t} & =\text { Sebelum ada komanajemen }
\end{array}
$$

Keputusan di mana kinerja komanajemen memberikan dampak merata bila:

$$
\begin{gathered}
\left|\mathrm{KKP}_{\mathrm{k}}\right|>\left|\mathrm{KKP}_{\mathrm{t}}\right| \text { atau bila } \\
\left|\mathrm{KKP}_{\mathrm{k}}\right| \approx\left|\mathrm{KKP}_{\mathrm{t}}\right| \text { dan } \overline{\mathrm{X}}_{\mathrm{k}} \ggg \overline{\mathrm{X}}_{\mathrm{t}}
\end{gathered}
$$

Kriteria keberlanjutan (sustainable) dievaluasi berdasarkan pengaruh komanajemen terhadap kelangsungan identitas sosial. Aspek yang dievaluasi yaitu kesempatan kerja dan ada tidaknya konflik antara komanajemen dengan budaya lokal.

\section{HASIL DAN PEMBAHASAN}

\section{Faktor Kontekstual Keberadaan Komanajemen}

\section{- Pemanfaatan kawasan pesisir}

Desa Jungut Batu terletak di Pulau Nusa Lembongan yang termasuk dalam Kecamatan Nusa Penida, Kabupaten Klungkung. Pulau Nusa Lembongan terletak paling barat di antara gugusan Kepulauan Nusa Penida. Di antara tujuh desa pantai yang ada di Kecamatan Nusa Penida, Desa Jungut Batu memiliki kawasan yang lengkap peruntukannya. Sepanjang pantai yang membentang dari arah barat hingga utara Pulau Nusa Lembongan tercatat ada enam kegiatan dan kawasan yang sangat mempengaruhi keadaan lingkungan pantai yaitu:

(a) Di sebelah barat sekitar 300-500 m dari pantai merupakan kawasan pariwisata laut (surfing, snorkeling, dan jetsky), selain itu juga terdapat tidak kurang dari 5 buah tambatan terapung bagi peruntukan kapal-kapal wisata dari Benoa.

(b) Di sepanjang pantai barat dan utara mulai dari $0-500 \mathrm{~m}$ tegak lurus pantai terdapat hamparan budidaya rumput laut yang diusahakan oleh nelayan setempat. Lahan usaha menempati perairan karang yang sudah rusak/ mati.

(c) Tepat di depan Desa Jungut Batu terdapat pendaratan bagi angkutan penyeberangan reguler dari dan ke Sanur yang menempati kawasan sekitar 200 m sejajar pantai.

(d) Sebelah timur laut hingga ke arah timur terdapat kawasan hutan bakau yang dilindungi seluas 202 ha. Hutan ini merupakan satu-satunya hutan lindung yang ada di Kecamatan Nusa Penida.

(e) Di sepanjang pantai utara Desa Jungut Batu terdapat kawasan penginapan dan restoran bagi wisatawan, dikelola oleh penduduk setempat.

(f) Sebelah utara (dekat mercu suar) terdapat kawasan pengambilan pasir sebagai bahan bangunan bagi penduduk setempat (non-komersial)

Kegiatan-kegiatan tersebut di atas terlihat tumpang tindih karena tata ruang bagi masing-masing kepentingan masih belum jelas.

\section{- Pemerintahan adat dan kependudukan}

Desa Jungut Batu berada di bawah pemerintahan Desa yang dipimpin oleh 
kepala Desa. Selain itu juga ada pemerintahan adat yang dipimpin oleh bendesa adat yang membawahi beberapa banjar adat (semacam dusun). Kepala pemerintahan desa membawahi empat dusun (rukun warga) yang terdiri atas delapan kampung (rukun tetangga). Sedangkan bendesa adat mem. bawahi delapan buah banjar adat. Masing. masing banjar adat dipimpin oleh kelian banjar adat (ketua banjar adat) dengan dibantu oleh tiga perangkat/aparat yaitu juru arah, juru sari dan penunggon (Gambar 2). Masing-masing memiliki tugas sebagai berikut:

(a) Juru arah, bertanggung jawab untuk menyampaikan berita kepada masyarakat adat yang berupa pengumuman, pemberitahuan dan ajakan. Perintah ini diberikan oleh bendesa adat.

(b) Juru sari, bertanggung jawab untuk mempersiapkan sarana dan prasarana bagi kepentingan upacara adat. Perintah diberikan oleh bendesa adat.

(c) Penunggon, bertanggung jawab menjaga keamanan dan kebersihan rumah ibadah.
Jumlah penduduk Jungut Batu pada tahun 1994 sebanyak 2874 jiwa yang terdiri atas 1476 wanita dan 1398 pria. Jumlah KK menurut pemerintahan desa sebanyak 543 KK. Sedangkan menurut pemerintahan adat menjadi sekitar $400 \mathrm{KK}$. Perbedaan ini disebabkan karena perbedaan perhitungan $\mathrm{KK}$ secara adat. Menurut adat apabila dalam satu keluarga memiliki tiga anak atau lebih, setelah menikah semua (memiliki keluarga sendiri) maka secara otomatis orang tuanya ikut sebagai anggota keluarga dari anak yang ketiga. Selain itu pendatang yang menganut agama lain (di luar Hindu), tidak termasuk dalam hitungan $\mathrm{KK}$ adat.

Pendatang yang menetap di Desa Jungut Batu sebagian berasal dari Pulau Nusa Penida dan lainnya berasal dari Jember (Jawa Timur). Alasan mereka ke Jungut Batu adalah untuk mengusahakan budidaya rumput laut dan sebagian kecil sebagai supir. Jumlah pendatang pada tahun 1994 tercatat 34 jiwa, sedangkan pada tahun 1995 (s/d April) sekitar 100 jiwa. Migrasi keluar pada tahun 1994 tercatat sebanyak 40 jiwa dengan tujuan utama Denpasar. Pada umumnya motivasi utama migrasi keluar adalah mencari pekerjaan dan karena menikah dengan orang luar.

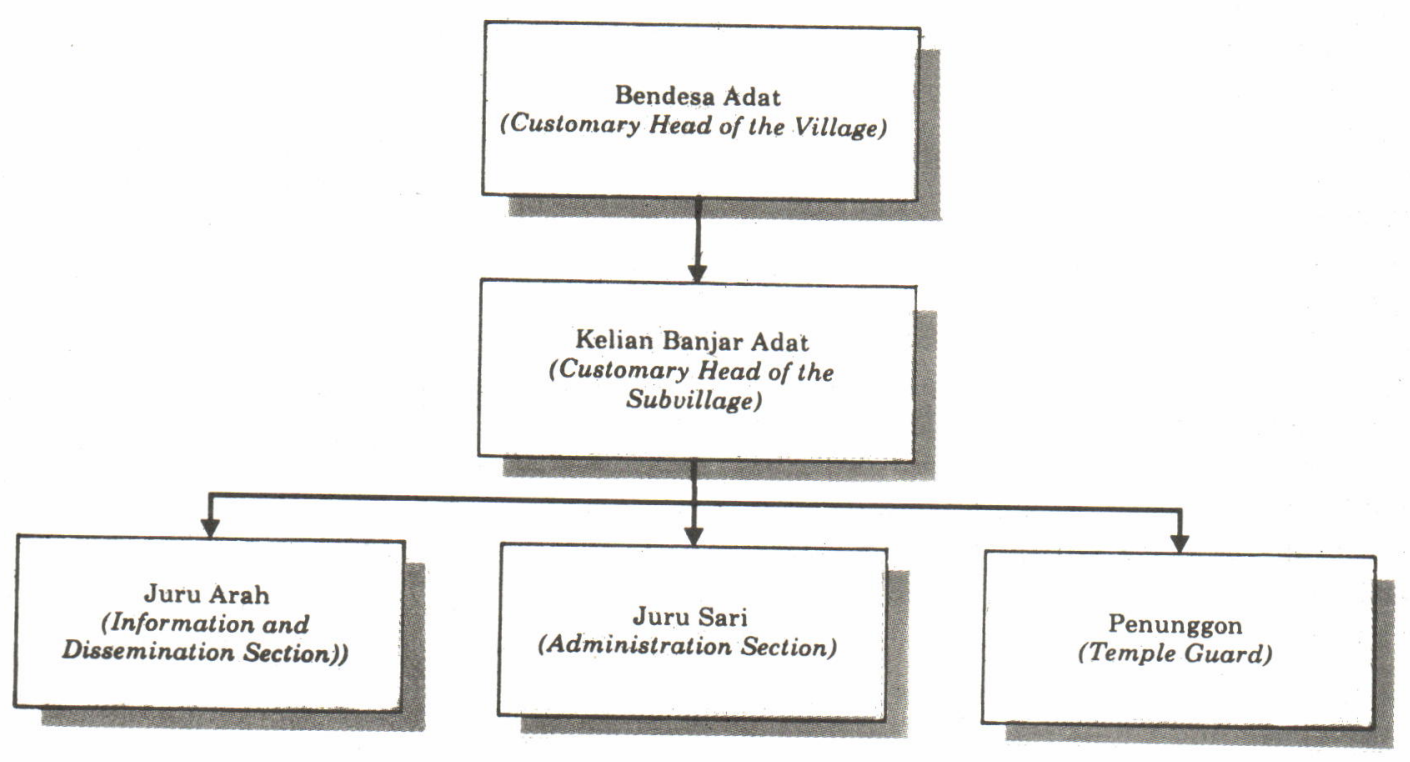

Gambar 2. Susunan organisasi institusi adat, Jungut Batu.

Figure 2. Organizational arrangement of customary institute, Jungut Batu. 


\section{- Mata pencaharian dan pergeseran ke usaha rumput laut}

Sebelum tahun 1984 mata pencaharian sebagian besar penduduk adalah nelayan dengan pekerjaan sampingan sebagai petani/ peladang. Seperti diketahui, musim penangkapan ikan hanya sekitar enam bulan dalam satu tahun dan trip penangkapan hanya dilakukan sekitar 12 jam/hari, sehingga waktu luang nelayan untuk kegiatan di darat praktis lebih banyak.

Menurut keterangan beberapa tokoh kunci (key person) pada tahun 1984-1985 sebagian nelayan berpindah menjadi petani rumput laut. Harga rumput laut pada waktu itu berkisar antara Rp150-Rp175,- per kg kering (untuk jenis Eucheuma spinossum). Pada tahun 1986 harga mulai meningkat dan nelayan mulai menanam jenis $E$. cotonii. Pada tahun 1991 harga mencapai puncak tertinggi, yaitu berkisar Rp1.500-Rp1850,per kg kering. Pada tahun tersebut sebagian besar nelayan (sekitar $60 \%$ nelayan) sudah berpindah menjadi petani rumput laut. Mereka menjual aset perikanan yang dimilikinya seperti mesin dan jaring dan digunakan sebagai modal penanaman rumput laut. Pada tahun 1993 terjadi penurunan harga yang cukup drastis di pasaran lokal. Harga jenis Eucheuma spinossum turun mencapai Rp300,- per kg kering, demikian pula untuk $E$. cottonii turun menjadi Rp450,per kg kering. Salah satu penyebab penurunan ini adalah ulah pedagang pengumpul yang memanipulasi berat dengan jalan merendam rumput laut yang telah kering ke dalam air laut. Hal ini menyebabkan kepercayaan pedagang besar (Surabaya dan Denpasar) menjadi berkurang. Pada tahun 1994 harga mulai meningkat kembali menjadi sekitar Rp.750-Rp. 1.100,- per kg. kering dan perpindahan nelayan menjadi petani rumput laut menjadi semakin banyak, yaitu mencapai sekitar $90 \%$ dari total jumlah nelayan.

Akibat dari berkurangnya nelayan maka pasokan ikan untuk konsumsi lokal menjadi berkurang. Bahkan untuk keperluan lokal, Desa Jungut Batu harus mendatangkan ikan dari daerah lain. Harga ikan menjadi tinggi dan terdapat indikasi berkurangnya konsumsi ikan oleh penduduk setempat.

\section{- Organisasi dan kelembagaan desa}

Ada dua jenis organisasi yang mengatur pemerintahan desa, yaitu organisasi formal di bawah pemerintah daerah dan organisasi informal di bawah pemerintah adat. Organisasi formal pemerintah Desa Jungut Batu memiliki aturan, struktur/susunan organisasi yang pada umumnya sama dengan desadesa lain di Indonesia. Sedangkan organisasi pemerintah adat disesuaikan dengan kebutuhan yang menyangkut masalah adat.

Selain organisasi pemerintahan, organisasi sosial dan kemasyarakatan perlu diketahui peranannya. Keberadaan organisasi di tingkat desa menunjukkan seberapa jauh penduduk mau bekerja sama. Selain itu pula kemauan berorganisasi menunjukkan keter. aturan dalam menyalurkan dan mengemukakan gagasan dan pendapat. Pada Tabel 1 dikemukakan jenis organisasi formal dan informal yang ada di Jungut Batu.

Dapat dilihat pada Tabel 1 bahwa organisasi formal umumnya merupakan organisasi yang pembentukan dan keberadaannya melalui inisiatif dari pemerintah di atas pemerintah desa. Tujuan organisasi formal secara umum adalah melaksanakan pembangunan desa dalam berbagai aspek. Dapat dikatakan bahwa sebagai konsekuensi dari inisiatif yang datang dari atas, dana untuk pelaksanaan program organisasi umumnya berasal dari pemerintah. Hanya pemerintah desa (kepala desa dan aparaturnya) serta LKMD memiliki program kerja yang berkaitan dengan pengelolaan kawasan pesisir. Organisasi informal seperti tertera pada Tabel 1 menggalang dana secara swadaya. Pemerintah adat Desa Jungut Batu memiliki program atau kegiatan yang berkaitan dengan pengelolaan kawasan pesisir, yaitu dalam hal penanaman rumput laut, pengambilan karang, kayu bakau dan pasir. Kelompok petani rumput laut adalah organisasi petani yang memusatkan kegiatannya 
Jurnal Penelitian Perikanan Indonesia Vol.II No. 1 Tahun 1996

مै

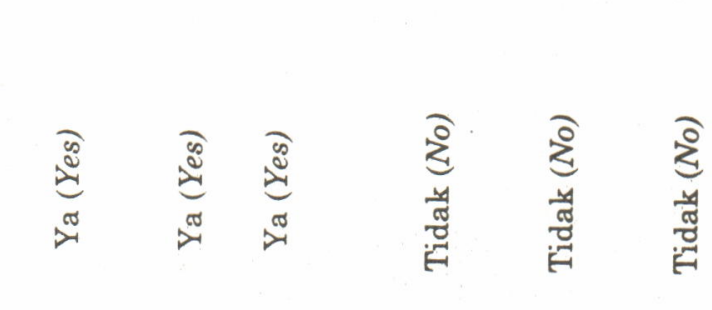
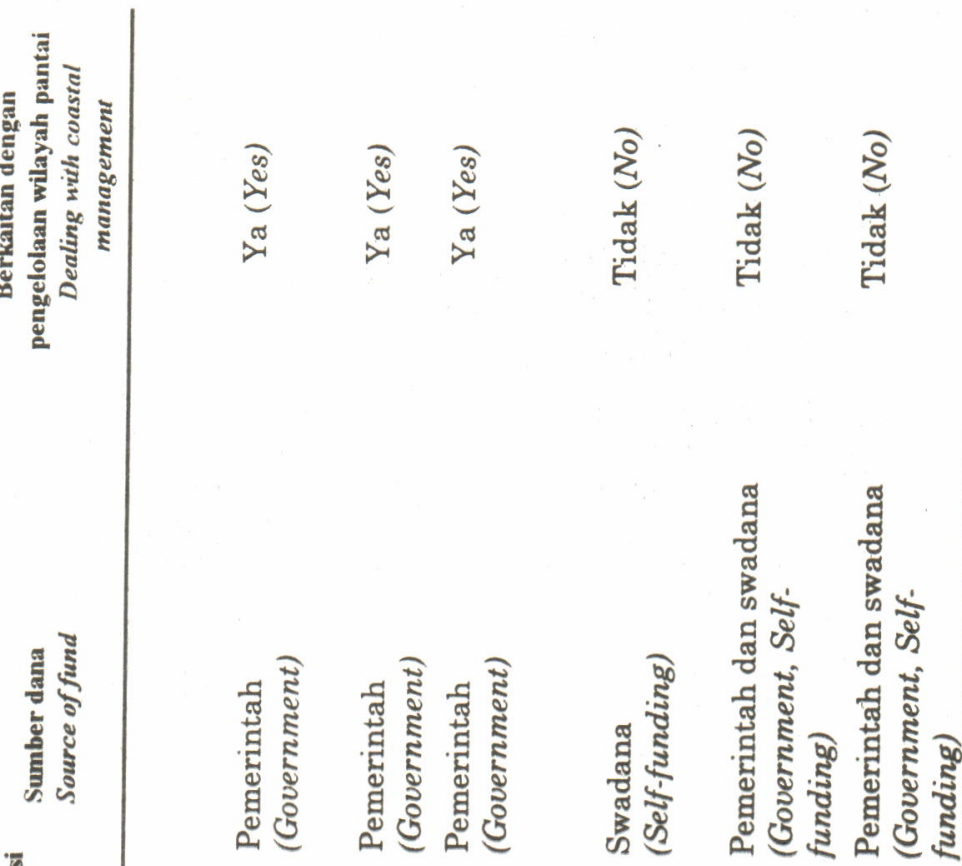

รี ริ มู่

๓

ปู

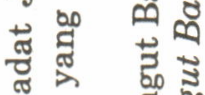

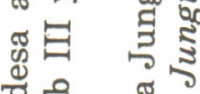

.

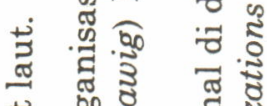

震

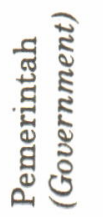

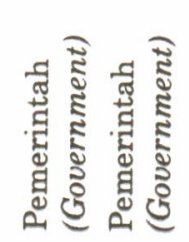

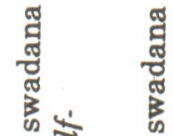

हूँ

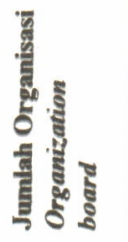

$9 \quad 19 \quad 1$

$=\quad 2$

ติ

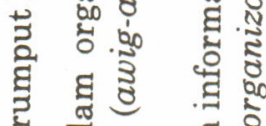

สี శ็ శ్ శี

ซี ซ

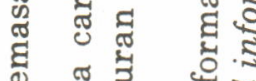

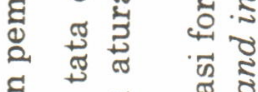

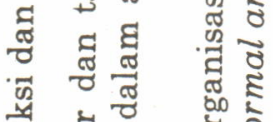

ज्ञ

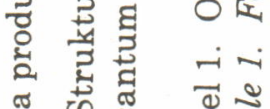

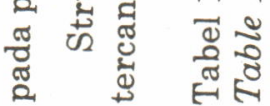

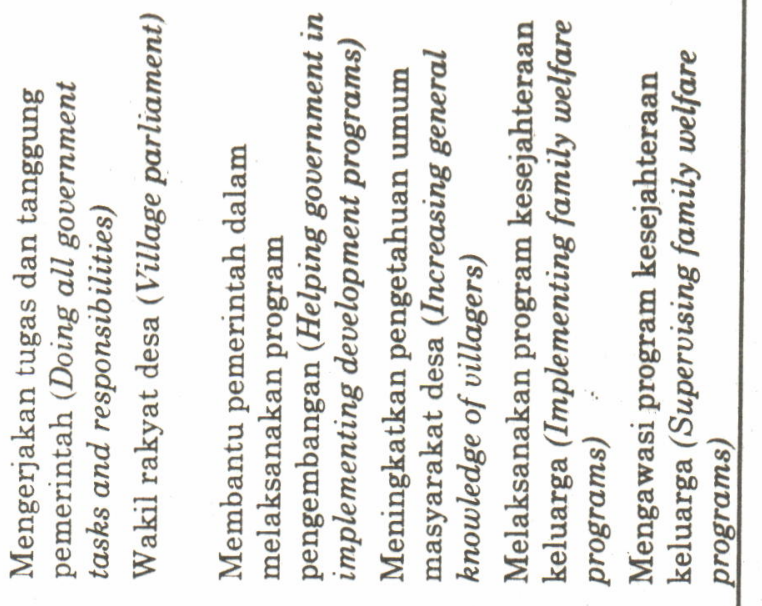

I

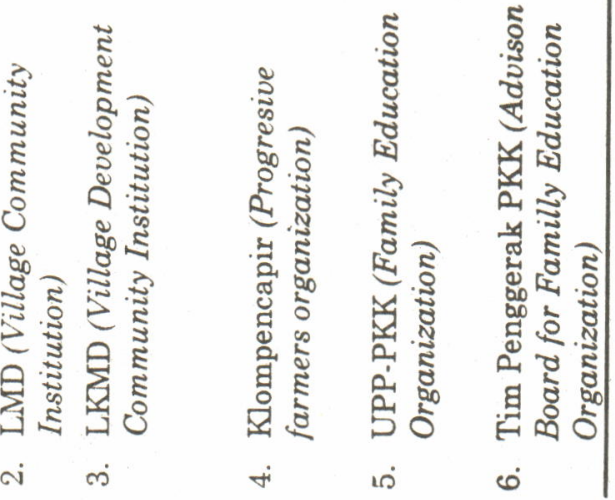


Basuki, R. dan Nikijuluw, V.P.H.

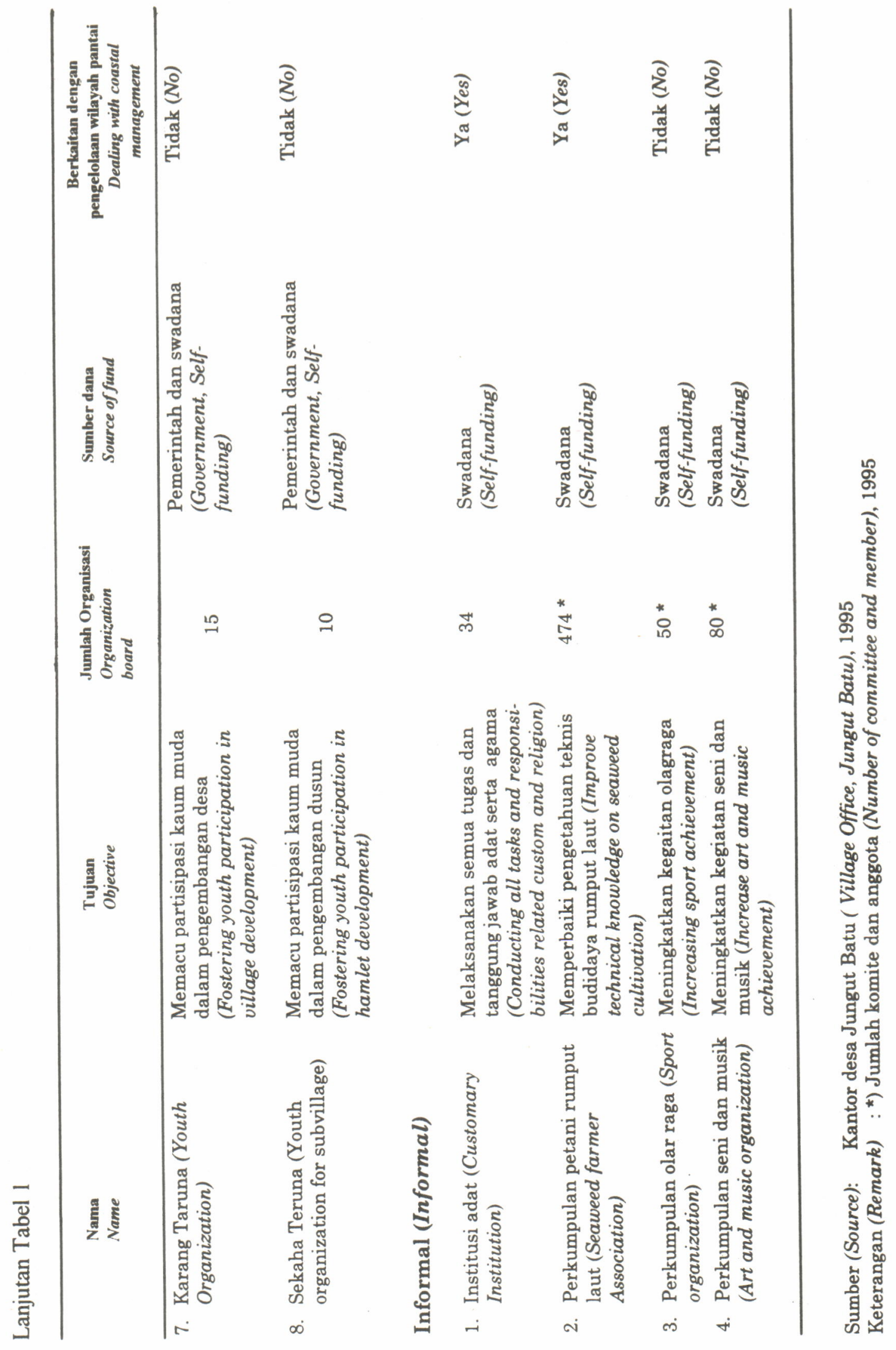




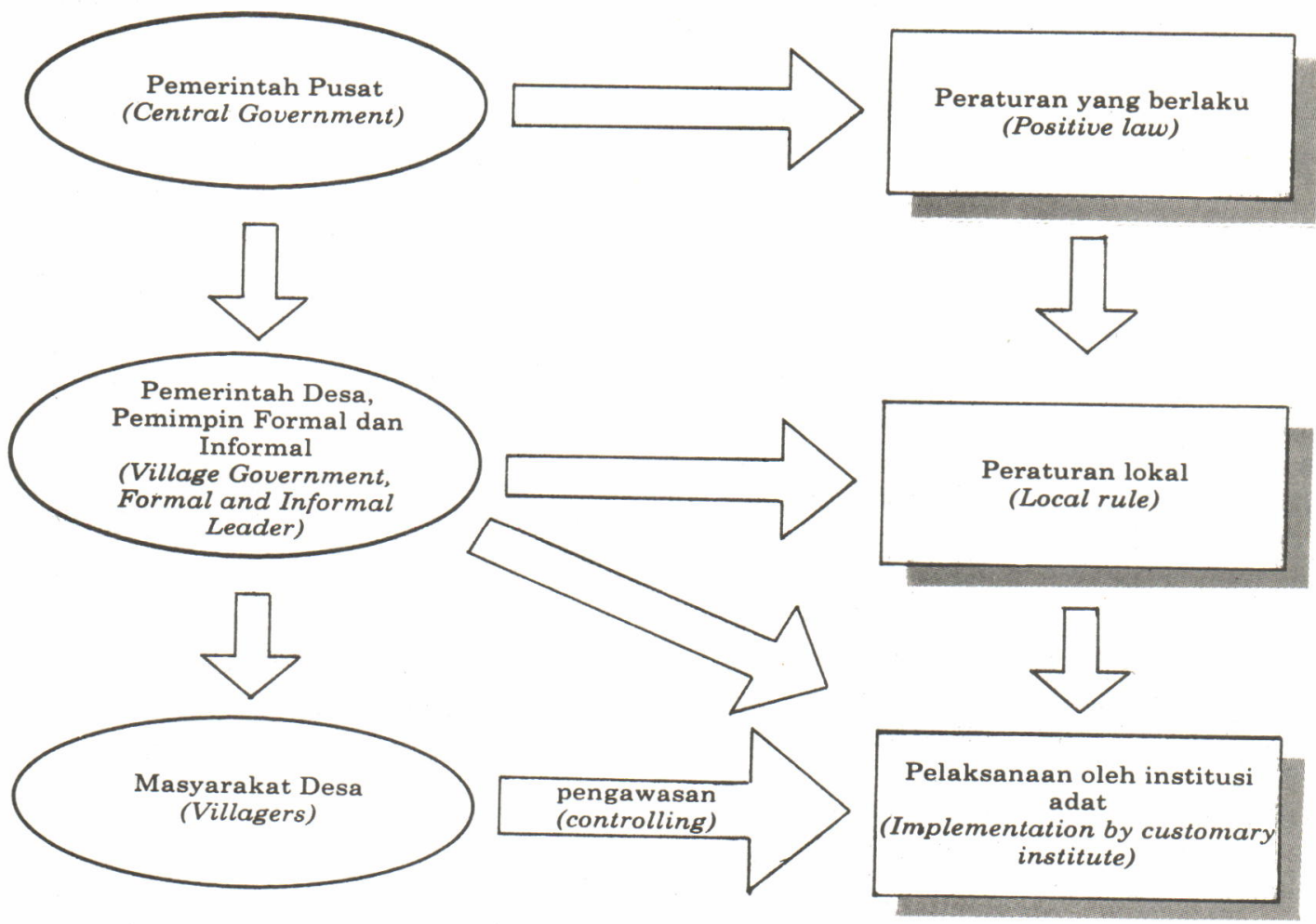

Gambar 3. Mekanisme pemahaman hukum yang berlaku ke dalam lokal di Jungut Batu. Figure 3. Mechanism of translating positive law into local rules in Jungut Batu.

Tatacara dalam pemilihan dan peng. angkatan bendesa adat dan kelian banjar adat adalah sebagai berikut :

(a) Pemilihan langsung, bila calonnya lebih dari satu dan memiliki kekuatan yang relatif sama.

(b) Secara formatur, bila calon sudah disepakati oleh dewan formatur. Anggota dewan formatur dipilih masyarakat sebanyak 10 orang yang biasanya terdiri atas tokoh masyarakat.

(c) Pemilihan bendesa adat dilaksanakan pada tingkat desa, sedangkan pemilih. an kelian banjar adat dilaksanakan pada tingkat yang lebih kecil, yaitu kampung. (d) Perangkat adat dipilih selama lima tahun, untuk kemudian kalau diperlukan bisa dipilih kembali.

(e) Seluruh perangkat adat tidak diberi upah tetapi dibebaskan dari tugas dan kewajiban kemasyarakatan (iuran wajib dan segala bentuk sumbangan, juga kegiatan pembangunan fasilitas umum).

Sumber dana bagi kas desa adat diperoleh dari masyarakat setempat (swadaya) yang berupa:

1. Iuran wajib setiap KK yang ditarik setiap pertemuan.

2. Sumbangan sukarela 
3. Hasil dari usaha simpan pinjam.

4. Hasil dari denda pelanggaran peraturan.

\section{Komanajemen Kawasan Pantai Jungut Batu}

\section{- Landasan esensial}

Peraturan pengelolaan pantai yang ditetapkan oleh adat secara tersirat tercantum dalam awig-awig (peraturan induk desa adat) Desa Jungut Batu. Awig-awig merupakan aturan turun-temurun yang tertulis dalam tulisan Kawi/Jawa kuno pada daun lontar, yang diterjemahkan dalam tulisan Latin dengan menggunakan bahasa Bali. Alih tulisan ini dilakukan pada tahun 1984, yang diterjemahkan ke dalam 8 sarga (bab) dan 92 pawes (pasal). Walaupun secara tersurat tidak tercantum dalam awig-awig, akan tetapi peraturan pengelolaan sumber daya pantai tersebut memiliki kekuatan hukum yang sama, seperti halnya yang diterapkan dalam awig-awig.

Peraturan pemanfaatan dan pengelolaan pantai yang kini berlaku di Jungut Batu pada dasarnya adalah suatu implementasi dari peraturan formal yaitu UU no. 4 tahun 1982 tentang Ketentuan-ketentuan Pokok Pengelolaan Lingkungan Hidup. Pemerintah dan pemuka adat desa menganggap bahwa apa yang dikemukakan dalam undang-undang ini cukup sulit untuk diterapkan secara lokal. Mengatasi hal ini, UU tersebut diterjemahkan secara parsial dalam peraturan yang bersifat lokal sehingga mudah dimengerti, diimplementasikan dan diawasi di lapangan. Proses terjemahan UU formal ke bentuk peraturan lokal dapat dilihat pada Gambar 3.

Isi peraturan yang menyangkut sumber daya pantai yang dibuat/ditetapkan oleh pemerintah desa, perangkat adat dan tokohtokoh agama/adat adalah sebagai berikut:

1. Masyarakat adat desa Jungut Batu dilarang mengambil dan memanfaatkan kayu bakau untuk kepentingan apapun.

2. Masyarakat adat desa Jungut Batu tidak diperkenankan mengambil batu karang karena dapat merusak ekosistem, menyebabkan abrasi pantai dan merusak keindahan.

3. Untuk kebutuhan pembangunan rumah tinggal maka pengambilan pasir pantai dialokasikan pada daerah tertentu di desa adat. Pengambilan pasir harus sepengetahuan bendesa adat (kepala adat) dengan jadwal waktu yang ditentukan dan banyaknya pasir yang diambil adalah sebatas kebutuhan (tidak untuk diperjual belikan).

4. Zonasi lahan budidaya rumput laut diatur sedemikian rupa, sehingga tidak mengganggu alur pelayaran dan kepentingan wisata bahari.

5. Apabila lahan budidaya selama tiga bulan terus menerus tidak ditanami/diusahakan, maka harus dialihkan pada orang lain yang dapat mengusahakannya.

Menurut Gambar 3, peraturan formal atau hukum positif dipelajari oleh kepala desa, kepala adat dan masyarakat untuk menentukan kemungkinan pelaksanaannya secara lokal. Hukum positif tersebut kemudian secara parsial diterjemahkan ke dalam peraturan lokal yang sesuai dengan kondisi masyarakat dan sumber daya alam. Pembuatan peraturan lokal juga berpedoman pada peraturan adat (awig-awig) yang terlebih dahulu sudah ada. Setelah dirumuskan, pelaksanaan peraturan lokal itu diserahkan kepada dan menjadi tanggung jawab pemerintah adat desa. Pada saat penelitian ini dilaksanakan peraturan lokal tersebut belum ditulis. Uraian mengenai peraturan lokal pengelolaan pantai dapat dilihat pada Tabel 2. Mekanisme penyebaran informasi peraturan lokal ini adalah sebagai berikut:

(a) pemberitahuan secara tidak langsung pada masyarakat melalui pemerintah adat, yaitu juru arah.

(b) pemberitahuan secara langsung dan terus menerus melalui rapat desa atau rapat banjar yang rutin dilakukan setiap 35 hari sekali. 
Tabel 2. Institusi dasar dan struktur organisasi hukum adat di desa Jungut Batu, Klungkung. Table 2. Institutional base and organizational structure of customary law in Jungut Batu Village, Klungkung.

\begin{tabular}{|c|c|}
\hline & $\begin{array}{c}\text { Deskripsi } \\
\text { Description }\end{array}$ \\
\hline Tujuan (Objective) & $\begin{array}{l}\text { 1. Pemanfaatan sumber daya pantai secara maksimal (Optimal } \\
\text { use of coastal resource) } \\
\text { 2. Peningkatan pendapatan nelayan/petani ikan (Increased } \\
\text { income of fishermen/fish farmers) } \\
\text { 3. Konservasi dan pelestarian sumber daya alam (Conservation } \\
\text { and sustainability of natural resource) }\end{array}$ \\
\hline $\begin{array}{l}\text { Norma yang berlaku } \\
\text { (Shared Norm) }\end{array}$ & $\begin{array}{l}\text { 1. Pelarangan penebangan kayu (Prohibition of mangrove } \\
\text { logging) } \\
\text { 2. Pelarangan penambangan koral (Prohibition of coral mining) } \\
\text { 3. Pengambilan pasir pantai diizinkan di areal tertentu (Beach- } \\
\text { sand collecting is allowed in certain area with no commercial } \\
\text { purpose). } \\
\text { 4. Budidaya rumput laut di wilayah perairan kurang dari } 100 \mathrm{~m} \\
\text { dari garis pantai (Seaweed cultivation is zoned at the waters } \\
\text { beyond } 100 \mathrm{~m} \text { from the coastal line) } \\
\text { 5. Pelarangan budidaya rumput laut pada areal perkapalan/alur } \\
\text { pelayaran (Prohibition to cultivate seaweed at shipping lane) }\end{array}$ \\
\hline Perilaku (Behaviour) & $\begin{array}{l}\text { 1. Seluruh masyarakat dilibatkan dalam budidaya rumput laut } \\
\text { (All villagers could involve in seaweed cultivation) } \\
\text { 2. Penduduk pendatang dapat dilibatkan di kegiatan budidaya } \\
\text { rumut laut dengan izin dari bendesa adat (Non-origin } \\
\text { villagers could involve in seaweed cultivation with permit from } \\
\text { "bendesa adat") }\end{array}$ \\
\hline $\begin{array}{l}\text { Struktur Organisasi } \\
\text { (Organizational Structure) }\end{array}$ & $\begin{array}{l}\text { 1. Peraturan lokal berdasarkan hukum formal yang berlaku } \\
\text { (Local rules are inspired by the positive and formal laws). } \\
\text { 2. Formulasi peraturan lokal dibuat oleh Kepala Desa, bendesa } \\
\text { adat dan pemimpin nonformal (Formulation of the local rules } \\
\text { is set by village chief, "bendesa adat" and non formal leaders). } \\
\text { 3. Pelaksanaan peraturan lokal dilakukan oleh bendesa adat } \\
\text { dengan diikuti oleh masyarakat desa (Implementation of the } \\
\text { local rules are undertaken by "bendesa adat" with auspice of } \\
\text { villagers). }\end{array}$ \\
\hline
\end{tabular}

Pada awalnya, semua kewajiban akibat yang tercantum dalam peraturan lokal ditujukan kepada masyarakat adat yaitu penduduk asli desa. Berhubung adanya migrasi dari luar, maka peraturan tersebut juga berlaku bagi masyarakat pendatang. Pada saat ini peraturan tersebut berlaku sama bagi masyarakat tanpa membedakan kasta, suku dan status sosial.
Hak yang diperoleh penduduk dalam pengelolaan pantai, khususnya budidaya rumput laut adalah sama. Dalam hal ini penduduk dibebaskan menanam rumput laut sesuai dengan kemampuan masing-masing pada lahan yang tersedia. Hak milik atas lahan tidak diperkenankan, karena apabila lahan yang diperolehnya tidak diusahakan selama tiga bulan berturut-turut maka hak 
pengusahaannya dicabut dan dipindahkan pada penduduk lainnya.

Ada beberapa alasan mengapa nelayan dan penduduk pantai mematuhi peraturan yang ditetapkan oleh adat :

1. Masyarakat Bali merupakan masyarakat religius yang memiliki ikatan kuat terhadap agama dan adat. Peraturan di dalam adat sebagian besar menyangkut tatacara menjalankan agama yang harus dipatuhi, sehingga peraturan yang ditetapkan adat di luar peraturan agama tersebut memiliki kekuatan hukum yang sama.

2. Hukuman yang ditetapkan oleh adat cenderung mengarah pada hukuman nonmateri yang bersifat sanksi sosial. Hukuman ini dirasakan lebih berat dibandingkan hukuman materi (denda) bagi masyarakat yang menjunjung tinggi martabat/ kehormatan.

3. Ada alternatif kegiatan usaha yang lebih ramah lingkungan daripada kegiatan destruktif yang sebelumnya dilaksanakan.

4. Kesadaran akan pentingnya menjaga kelestarian lingkungan bagi sebagian penduduk pantai telah muncul semenjak mereka merasakan adanya abrasi pantai yang semakin parah, yang diakibatkan oleh pengambilan karang. Menurut penduduk setempat pada waktu peng. ambilan karang masih berlangsung, penduduk yang tinggal di tepi pantai harus memperbaiki tanggul penahan ombak minimal 3 kali dalam setahun. Setelah pelarangan pengambilan karang dan semakin banyak penanaman rumput laut di tepi pantai, maka perbaikan tanggul penahan ombak hanya dilakukan paling banyak sekali dalam setahun.

\section{- Pelaksanaan dan sanksi pelanggar- an peraturan komanajemen}

Pelaksanaan peraturan tentang pengelolaan sumber daya pantai dilakukan aparat pemerintah desa adat dengan dibantu oleh masyarakat setempat. Apabila terjadi pelanggaran, maka penerapan sanksi dilakukan oleh bendesa adat. Peraturan secara tertulis belum ada, tetapi secara tidak tertulis disampaikan kepada dan dimengerti oleh masyarakat.

Daerah pantai yang dilindungi oleh peraturan adat adalah sepanjang pantai desa (sekitar $6.000 \mathrm{~m}^{2}$ ) dan daerah karang di sekitar desa. Sedangkan di daratan meliputi areal 202 ha hutan bakau (mangrove) yang terletak di sebelah utara desa.

Tidak semua peraturan yang ditetapkan adat berjalan efektif. Sebagai contoh adalah penetapan batas tanaman rumput laut dan penetapan alur pelayaran. Dua hal ini masih belum dilaksanakan sepenuhnya karena sebagian anggota masyarakat merasa keberatan untuk mengalihkan lahan budidayanya. Dalam hal ini pimpinan adat tidak memberikan hukuman sebagaimana pada Tabel 3, karena peraturan sanksi belum dirumuskan oleh ketua adat.

Sanksi yang diterapkan dalam peraturan berupa sanksi sosial dan sanksi moneter. Penerapan sanksi sosial berupa kerja paksa di pura dan banjar selama waktu yang ditentukan. Penerapan sanksi moneter berupa denda sejumlah uang tertentu sesuai dengan tingkat pelanggaran. Jenis-jenis pelanggaran dan sanksinya tertera pada Tabel 3.

\section{- Evaluasi dampak komanajemen}

Komanajemen kawasan dan sumber daya pesisir di Desa Jungut Batu, Bali adalah salah satu bentuk kebijakan bersama antara pemerintah dan masyarakat adat. Dalam hal ini, masyarakat mencoba menterjemahkan peraturan pemerintah pusat ke dalam suatu bentuk peraturan praktis yang sesuai dengan kondisi lokal. Dengan cara ini peraturan pemerintah pusat tadi dapat dilaksanakan dengan lebih mudah. Demikian pula pemantauan pengendalian dan kontrol di lapangan dapat dengan efektif dikerjakan, karena hal ini merupakan tanggung jawab penduduk dan pimpinan adat.

Bentuk komanajemen seperti ini tampaknya tidak sesuai benar dengan bentukbentuk dalam hirarki komanajemen yang dikemukakan oleh Pomeroy dan Williams (1994) pada Gambar 1. Dapat dikatakan bahwa hal ini adalah suatu "kebijakan bersama", namun dalam kenyataannya masya- 
Tabel 3. Pelanggaran dan sanksi komanajemen terpadu di desa Jumput Batu, Klungkung, 1995.

Table 3 Violations and sanctions of co-management in Jungut Batu, Klungkung, 1995.

\begin{tabular}{|c|c|c|}
\hline $\begin{array}{c}\text { Pelanggaran } \\
\text { Violations } \\
\end{array}$ & $\begin{array}{c}\text { Sanksi } \\
\text { Sanctions } \\
\end{array}$ & $\begin{array}{c}\text { Efektivitas } \\
\text { Effectiveness } \\
\end{array}$ \\
\hline $\begin{array}{l}\text { Penebangan mangrove (Mangrove } \\
\text { logging) }\end{array}$ & $\begin{array}{l}\text { Denda Rp } 50.000 \text { per pelanggaran } \\
\text { (Fine: } R p 50.000 \text { per violation) }\end{array}$ & Ya $(Y e s)$ \\
\hline Penambangan koral (Coral mining) & $\begin{array}{l}\text { Bekerja sosial selama 3-7 hari } \\
\text { (Social works for } 3-7 \text { days) }\end{array}$ & Ya (Yes) \\
\hline $\begin{array}{l}\text { Pengambilan pasir pantai (Beach sand } \\
\text { taking) }\end{array}$ & $\begin{array}{l}\text { Bekerja sosial selama 3-7 hari } \\
\text { (Social works for 3-7 days) }\end{array}$ & Ya (Yes) \\
\hline $\begin{array}{l}\text { Budidaya rumput laut di areal terlarang } \\
\text { (Culturing seaweed in prohibited areas) }\end{array}$ & Peringatan (Warning) & Tidak (No) \\
\hline $\begin{array}{l}\text { Membiarkan terlantar areal yang } \\
\text { sesungguhnya produktif untuk budidaya } \\
\text { rumput laut (Letting the potential } \\
\text { seaweed area idles) }\end{array}$ & Peringatan (Warning) & Ya (Yes) \\
\hline $\begin{array}{l}\text { Menanam rumput laut di alur pelayaran } \\
\text { (Culturing seaweed on shipping lane) }\end{array}$ & Peringatan (Warning) & Tidak (No) \\
\hline
\end{tabular}

Sumber (Source): Hukum adat tak tertulis Desa Jungut Batu (Unwritten customary law, Jungut Batu Village)

rakat desa hanya menggunakan peraturan pusat sebagai rujukan. Kalau disebut sebagai bentuk "konsultasi", hal ini tampaknya tidak sepenuhnya benar karena pada dasarnya tidak ada hubungan dua arah antara pemerintah pusat dan masyarakat desa. Malahan barangkali dapat dikatakan bahwa apa yang dilakukan oleh pemerintah desa ini tidak dimaklumi oleh pemerintah pusat. Dengan demikian komanajemen dalam bentuk men. terjemahkan atau mengkondisikan peraturan pusat ke dalam bentuk peraturan lokal atau setempat adalah suatu bentuk komanajemen baru yang perlu dimasukkan dalam hirarki komanajemen yang sudah ada.

Bila pemerintah desa (Kepala desa dan aparatnya menurut UU No. 5 tahun 1974 tentang Pokok-pokok Pemerintahan di Daerah) dapat dipandang mewakili unsur pemerintah pusat, maka komanajemen yang ada di Jungut Batu ini adalah suatu bentuk "kemitraan" di mana unsur pemerintah dan masyarakat mewakili peranan yang sebanding baik dalam pembentukan maupun dalam pelaksanaan peraturan lokal.

Adanya komanajemen di Desa Jungut Batu dapat dikatakan sebagai refleksi dari struktur ekonomi, sosial dan budaya yang ada. Secara ekonomis, pemanfaatan sumber daya pantai berupa pengambilan kayu bakau, pengambilan karang dan penangkapan ikan hias dengan alat tangkap destruktif mengakibatkan kemunduran kualitas sumber daya pantai. Masyarakat sendiri menyadari bahwa bila kegiatan ini tetap berlanjut, usaha mere. ka akan berhenti. Dengan adanya keinginan pemerintah untuk melestarikan lingkungan serta adanya permintaan pasar akan rumput laut, masyarakat, pemerintah desa dan pemerintah adat mengadakan pengaturan peman. faatan kawasan pesisir. Pengambilan kayu bakau dan karang dihentikan serta diadakan pewilayahan (zonasi) untuk penanaman rumput laut. 
Kondisi sosial budaya mendukung terlaksananya komanajemen kawasan pantai. Secara turun-temurun masyarakat memiliki peraturan lokal di tingkat desa yang dikenal dengan awig-awig. Hal ini berarti bahwa pengaturan oleh masyarakat sendiri bukan merupakan suatu hal baru. Adanya organisasi sosial informal di tingkat desa menunjukkan bahwa masyarakat memiliki potensi untuk berorganisasi. Keterkaitan yang kuat antara ajaran agama, adat serta kaidah kehidupan bermasyarakat menjamin terlak. sananya komanajemen sesuai dengan peraturan yang ditetapkan.

Dampak komanajemen bagi masyarakat nelayan yang beralih usaha pada budidaya rumput laut dapat dilihat dari adanya peningkatan pendapatan absolut bulanan. Tanpa komanajemen, pendapatan nelayan adalah sekitar Rp62.000,- per bulan. Namun dengan adanya komanajemen dan setelah nelayan beralih pekerjaan menjadi petani rumput laut pendapatan menjadi lebih dari Rp140.000,- per bulan (Tabel 4). Uji beda rata-rata berpasangan menunjukkan bahwa perbedaan pendapatan ini sangat nyata secara statistik. Namun harus diingat bahwa perbedaan absolut ini tidak atau belum mempertimbangkan laju inflasi. Karena ratarata perbedaan pendapatan ini lebih dari dua kali, maka secara absolut dapat dikatakan bahwa komanajemen memberikan dampak yang positif.

Tabel 4. Tingkat pendapatan dengan dan tanpa manajemen terpadu di Jungut Batu, 1995. Table 4. Income level with and without co-management in Jungut Batu, 1995.

\section{Deskripsi (Description)}

\section{Tanpa komanajemen (Without co-management)}

1992

40.000

100.000

$16.178,36$

0,187

Kecenderungan (Skewness)

Persentase kumulatif kelas pendapatan

$\mathrm{Rp} / \mathrm{bulan}$ (Cummulative percentage of

income classes $(X)(R p /$ month $)$ :

$$
\mathrm{X}<70000
$$

$70000 \leq \mathrm{X}<120000$

$120000 \leq \mathrm{X}<170000$

$170000 \leq \mathrm{X}<220000$

$220000 \leq \mathrm{X}<270000$

$270000 \leq \mathrm{X}<320000$

\section{Dengan komanajemen (With co-management)} 1995

75.000

300.000

$140.178,57$

$56.805,09$

1,236

\begin{tabular}{cc}
$53,57 \%$ & $0,00 \%$ \\
$100,00 \%$ & $39,29 \%$ \\
- & $78,57 \%$ \\
- & $85,71 \%$ \\
- & $96,43 \%$ \\
- & $100,00 \%$ \\
\hline
\end{tabular}

Efisiensi komanajemen dapat dilihat juga dari jumlah penyerapan tenaga kerja. Dengan adanya komanajemen setiap pemilik usaha mempekerjakan 1 atau 2 orang lebih banyak dari jumlahnya pada saat tanpa komanajemen. Hal ini berarti bahwa komanajemen membuka peluang kerja dan kesempatan berusaha. 
Pada Tabel 4 dapat dilihat tingkat keme. rataan pendapatan. Nilai KKP menunjukkan bahwa sebelum berlakunya komanajemen pendapatan bulanan lebih merata dibanding. kan setelah adanya komanajemen. Pertum. buhan yang tinggi (peningkatan pendapatan) setelah komanajemen ternyata tidak diikuti oleh pemerataan yang lebih baik. Hasil uji ini diperjelas lagi dengan distribusi frekuensi pendapatan (Tabel 4). Sebelum adanya peraturan, sebanyak $53.57 \%$ nelayan memiliki pendapatan di bawah Rp70.000,- sisanya berpendapatan antara Rp70.000-Rp120.000,-. Setelah diberlakukannya komanajemen, tidak ada petani rumput laut yang sebelumnya adalah nelayan memiliki pendapatan di bawah Rp70.000,- per bulan. Sekitar $40 \%$ memiliki pendapatan di antara $R p 70.000$. Rp120.000,-. Sedangkan sisanya (60\%) memiliki pendapatan diatas Rp120.000,- per bulan.

Bila melihat bahwa nelayan/petani ikan memiliki mata pencaharian yang relatif seragam, seharusnya pendapatan yang diperoleh juga tidak jauh berbeda. Akan tetapi penguasaan lahan yang sangat bervariasi dari 0,02-0,15 ha, menyebabkan tingkat pendapatan juga bervariasi. Tambahan pula dari hasil pengamatan, faktor lokasi tampaknya juga menentukan tingkat produktivitas lahan.

Dari aspek keberlanjutan, dapat dikemukakan bahwa komanajemen memberikan dampak positif. Keragaman sumber daya hayati (biodiversity) terjaga dengan cukup baik. Perpindahan nelayan menjadi petani rumput laut setidaknya mengurangi eksploitasi yang berlebihan terhadap sumber daya ikan di perairan sekitar desa. Demikian pula, makin berkembangnya wisata bahari di desa tersebut menyebabkan kesadaran penduduk pantai untuk menjaga lingkungan pesisir semakin besar, terutama terhadap perairan karang dan kebersihan lingkungan pantai. Nilai budaya lokal juga semakin diperkaya dengan masuknya unsur-unsur pengaturan lingkungan pantai ke dalam awig-awig. Faktor lain yaitu mata pencaharian masyarakat, tampaknya juga semakin baik. Pada saat nelayan masih beroperasi di laut, mereka hanya memiliki kesempatan berusaha sekitar 6 bulan. Setelah itu mereka mengerjakan lahan yang hanya bisa ditanami ketela pohon. Saat ini penanaman rumput laut bisa dilakukan selama 9 bulan dengan hasil yang jauh lebih memadai.

Secara keseluruhan dapat dikatakan bahwa kinerja dari peraturan pengelolaan pantai di Desa Jungut Batu dapat meningkatkan pendapatan masyarakat pantai, dengan tidak mengurangi/menghilangkan budaya lokal yang ada. Akan tetapi, dilihat dari segi pemerataan masih terjadi ketidak merataan yang cukup tinggi karena luas pengusahaan lahan yang tidak seragam.

\section{KESIMPULAN}

1. Komanajemen kawasan pantai Desa Jungut Batu sudah berjalan sejak tahun 1984 dan secara umum dapat dikatakan cukup efektif. Bentuk komanajemen ini merupakan hubungan kemitraan antara pemerintah desa, pemerintah adat dan masyarakat. Peraturan komanajemen pada dasarnya merupakan implementasi dari UU No.4 tahun 1972 tentang Ketentuan-ketentuan Pokok Pengelolaan Lingkungan Hidup. Khusus untuk budi-daya rumput laut, peraturan lokal mulai berlaku pada tahun 1994, bertepatan dengan beralihnya nelayan menjadi petani rumput laut.

2. Keberhasilan pelaksanaan komanajemen di Desa Jungut Batu karena adanya kepentingan masyarakat yang sama dalam menjaga kualitas lingkungan perairan pantai bagi usaha budidaya rumput laut. Faktor lain yaing turut menentukan efektifnya pelaksanaan komanajemen adalah dukungan karakter sosial budaya dan agama.

3. Bentuk komanajemen terdiri atas peraturan lokal yang menyangkut pengambilan karang, kayu bakau serta area penanaman rumput laut. Peraturan ini disertai sanksi bagi pelanggar.

4. Dengan adanya komanajemen di Desa Jungut Batu, pendapatan nominal masyarakat meningkat dengan tajam. Sementara itu kesempatan usaha sebagai petani rumput laut makin terbuka yang makin menyerap banyak tenaga kerja lokal. 
Masyarakat tetap bekerja di sektor perikanan seperti sebelumnya, yang berarti juga komanajemen tidak menghilangkan budaya lokal yang ada. Dengan beralihnya usaha nelayan ke petani rumput laut, pengusahaan terhadap sumber daya ikan dapat berkurang dan "tragedi milik bersama" yang digambarkan oleh rendahnya pendapatan dapat dihindari. Dari segi pemerataan hasil, masih terdapat ketimpangan pendapatan yang cukup tinggi karena perbedaan luas areal usaha rumput laut.

\section{DAFTAR PUSTAKA}

Berkes, F. 1994. Co-management: Bridging the two solitudes. North Perspective, 22 (2-3): 18. 20.

Jentoft, S. 1989. Fisheries Co-management. Delegating Government Renponsibillity to Fishermen's Organizations. Marine Policy, April 1989: 137 - 154.

Korten, F.F. 1981. Community Participation: A Management Perspective on Obstacles and
Options. In: D.C. Korten and F.B. Alfonso (Eds) Beureaucracy and the Poor: Closing The Gap. Asian Institute of Agric. Extension, Manila.

McCay, B.J. 1993. Management Regimes. Beijer Discussion Paper Series, No. 38.

Nikijuluw V.P.H. 1994. Sasi sebagai Suatu Pengelolaan Sumber daya Berdasarkan Komunitas di Pulau Saparua, Maluku. Jurnal Penelitian Perikanan Laut 93 : 79 - 92.

Pomeroy, R.S. 1994. A research Framework for Coastal Fisheries Co-management Institutions. ICLARM, Manila.

Pomeroy, R.S. and M.J. Williams. 1994. Fisheries Co-management and Small-Scale Fisheries: A Policy Brief. ICLARM, Manila.

Pomeroy, R.S. and M.D. Pido. 1995. Initiatives towards Fisheries Co-management in the Philippines. The Case of San Miguel Bay. Marine Policy 19 (3) : 213 - 226.

Walpole, R.E. 1982. Introduction to Statistics. Third Edition. MacMillan Publishing Co. Inc. New York. 